\title{
Comunicação internacional e intercultural \\ A luta pelo imaginário social, o temor à segregação e o caso do terrorismo
}

\author{
Jacques A. Wainberg*
}

\section{Introdução}

A revolução nas tecnologias de transporte e comunicação ocorrida no mundo, em especial após a Segunda Guerra Mundial, permitiu que pessoas de distintas etnias, nacionalidades, raças e religiões passassem a conviver em grau crescente de intimidade, no que se convencionou chamar de ambientes multiculturais. Esta proximidade física entre estranhos tornou-se ainda mais dinâmica à medida que as relações internacionais tornaram-se menos tensas, em especial no período após a queda do Muro de Berlim, em 1989, até o ataque terrorista às torres gêmeas de Nova York, em 11 de setembro de 2001. Nestes 12 anos, parecia aos olhos de todos que começávamos a viver uma era de paz e entendimento. Na verdade, o primeiro sinal desta mudança começara em 1988 quando as estatísticas revelavam queda no número de incidentes terroristas no mundo. O auge tinha ocorrido no período de 1971 a 1987, com um crescimento de 238 incidentes no primeiro ano e a mais de 700 ataques

* Doutor em Jornalismo pela ECA/USP, professor de Jornalismo e Comunicação da Faculdade de Comunicação Social da Pucrs. E-mail: jacqalwa@pucrs.br

\begin{tabular}{|l|l|l|l|l|l|}
\hline Civitas & Porto Alegre & v. 5 & n. 2 & jul.-dez. 2005 & p. 275-295 \\
\hline
\end{tabular}


no último. Em 1996, tais ocorrências tinham caído a um nível inferior ao verificado em 1971. O número de vítimas também diminuíra: 4.833 na década de 1980 e 2.527 nos anos 90. Tais dados, levantados por Johnson, levariam este autor a afirmar, pouco antes do ataque a Nova York, que: "a ameaça do terrorismo parece ser muito menos grave" (do que o imaginado) (Johnson, 2001, p. 894).

$\mathrm{Na}$ era fundamentalista do século XXI, tal assertiva soa estranha e nos parece um equívoco profético de grande proporção. Mas era o que se sentia à época. Outros sinais de relaxamento ajudavam tal miragem. Entre eles, o fato de que o conflito entre as potências e seus aliados desaparecia a passos largos. A Comunidade Européia dispunha-se a acolher países do antigo bloco comunista e a Organização do Tratado do Atlântico Norte, em crise de identidade, reavaliava sua função na era pós-guerra fria. Acrescente-se ainda o fato da Organização das Nações Unidas ter declarado 1986 o Ano da Paz, apesar de estarem em andamento naquele exato momento 15 guerras que produziam cerca de 1.000 mortes a cada ano.

A verdade é que a ansiedade por Paz jamais cedera. Guerra e Paz têm sido os dilemas centrais das relações internacionais desde o alvorecer da história. Cabe lembrar que desde a Segunda Guerra Mundial até 1992 ocorreram 150 guerras e que nelas morreram aproximadamente 20 milhões de pessoas. Incluindo vários tipos de outros conflitos, pereceram, desde 1945, entre $100 \mathrm{e}$ 150 milhões de pessoas. Neste período, tivemos somente 26 dias de paz se considerarmos somente guerras entre nações. Se incluirmos outras categorias de conflito, chegaremos à conclusão de que não houve na verdade um único dia de paz no mundo. A estatística histórica fala em cerca de 3.500 grandes guerras e cerca de 10.500 conflitos menores desde 3600 a.C. totalizando cerca de um bilhão de mortes diretas. Isso nos leva a concluir que a guerra é um estado natural de relações humanas e tem sido assim desde o alvorecer da história.

Mas, a miragem de uma era de tolerância crescente e pacificação do universo também era robusta a partir de 1987, porque, em grande medida, prevaleciam no interior das sociedades democráticas visões contrárias ao preconceito religioso e racial. Falava-se com orgulho do respeito à diferença. Tal cenário de aparente calmaria acabaria reforçado ainda com mudanças graves e favoráveis aos direitos humanos em vários cantos do mundo. Regimes auto- 
ritários sucumbiram em vários quadrantes do globo. Foi o caso das revoluções civilistas na Romênia, Albânia e nos Balcãs. Singularidades culturais e nacionais encontraram espaço no redesenho político implementado na antiga arquitetura política da União Soviética. O regime do apartheid da África do Sul igualmente chegara ao fim. Acrescente-se a isso, o mundo celebrava uma ilusão: a pacificação do conflito palestino-israelense, graças ao Acordo de Oslo. No extremo-oriente, negociações com a Coréia do Norte pareciam ter sido capazes de conter seu ameaçador programa nuclear. Na China, a abertura econômica estimulava os negócios e a descolonização de Hong Kong e outros enclaves ocidentais na região aliviava focos de tensão entre Pequim e o Ocidente. O mundo respirava aliviado. Falava-se com alegria do fim da história.

Entre as primeiras conseqüências deste novo clima psico-social otimista estava o surgimento de um intenso desejo humano de explorar territórios além-fronteira, como se viu em Berlim, logo após a queda do regime da Alemanha comunista. Famílias inteiras do leste puseram-se a caminho rumo ao oeste em viagens de passeio. O turismo tornou-se rapidamente na maior indústria do mundo (superando a do petróleo e a do armamento) e o sentimento de liberdade que o livre andar proporcionou após o fim às rígidas barreiras policiais fronteiriças serve-nos como emblema de um mundo que parecia nascer: uma civilização mais disposta ao contato, às trocas e aos afagos. Há que se documentar esta tendência com o fato de que em 1999, por exemplo, contabilizara-se 664 milhões de turistas internacionais. Este total tinha sido de somente 327 milhões em 1985 (Organização Mundial do Turismo, agosto de 2000). As fronteiras para tal andar tinham sido ampliadas fazendo com que tal peregrinação incluísse territórios antes excluídos ou vigiados, como é o caso da Polônia que registrou a chegada de 18 milhões de visitantes em 1998. Fenômeno similar ocorrera com a República Checa (16 milhões) e a Hungria (15 milhões) entre outros destinos antes inacessíveis ou intensamente controlados.

Outros sinais emergentes ainda ajudaram na mudança deste estado de espírito, entre eles o crescimento das trocas comerciais internacionais entre continentes, em especial entre o ocidente com o leste europeu e a Rússia; a ampla difusão sem censura e controles em todo o mundo de produtos simbólicos, como a música, a moda, o cinema, livros e revistas, e de programas de TV e jornalismo; a expansão de ambientes cosmopolitas em cidades e universidades; a aceleração dos negócios nos mercados globais de capitais, disse- 
minando os valores do capitalismo a regiões antes hostis à competição comercial; a democratização da América Latina, e o fim da tensão entre a Aliança Atlântica e o Bloco de Varsóvia.

Conceitos como mundialização, globalização, sociedade pós-industrial e pós-moderna, além de metáforas como as da cabana eletrônica e cibercultura sucederam à consagrada profecia dos anos 60 de Marshall McLuhan de que na era da eletricidade viveríamos todos numa aldeia global.

$\mathrm{Na}$ verdade, as fronteiras tinham se tornado neste curto interregno de pacificação, muito mais porosas do que em qualquer outro momento da história humana. Na Europa, aos poucos, nasce um novo cidadão: o da Comunidade Européia. Um ser continental. Do outro lado do Atlântico, os Estados Unidos continuariam assediados por uma massa de imigrantes, em especial hispânicos, que se tornam, no alvorecer do século XXI, na maior das minorias daquele país, superando os afro-descendentes. Em decorrência, seu destino histórico de ser uma nação multicultural acabaria reforçado.

Este fenômeno de vizinhanças cada vez mais heterogêneas ocorreu e permanece em desenvolvimento também na Austrália, no Canadá, na Inglaterra, na Nova Zelândia, entre outros centros cujas capitais e cidades importantes tornaram-se babéis lingüísticas.

Vista desde longe, a Terra parecia em relativa convulsão amistosa. $\mathrm{O}$ isolamento típico de épocas passadas, que assegurava às comunidades certa intimidade e sensação de segura identidade, começava a desmoronar. Paradoxalmente, a rapidez deste processo de enredamento tornou os problemas humanos de relações entre grupos mais expostos. Clamores que se queixavam contra a perda de soberania e/ou que abominavam a perda de uma imaginada essência em decorrência de uma superexposição à influência estrangeira logo se fizeram ouvir com vigor em nações tão díspares como as Filipinas, Indonésia, Arábia Saudita, Paquistão, Afeganistão, Irã e Iraque, mas também no ocidente, em especial nos países em desenvolvimento do sul que se queixavam agora de um novo tipo de imperialismo: o cultural. Discursos fundamentalistas de inspiração islâmica, nacionalista e xenófoba, como os da direita austríaca e francesa, por exemplo, encontraram simpática recepção em massas humanas que aspiravam ao expurgo de marcas culturais estranhas à sua própria identidade, considerada por estes nativos como a matriz cultural preferencial. 
$\mathrm{O}$ ataque às torres em Nova York daria visibilidade à hipótese de Hungtington (1997): pareceu a todos que terminara naquele momento a lua de mel intercultural. No horizonte passa a predominar a partir de então o temor por uma nova guerra civilizacional (fala-se agora, aos sussurros, de cruzadas, ora dos radicais de Osama Bin Laden contra o ocidente judaico-cristão, e às avessas, do ocidente sustentando sua sanha colonial em busca do domínio do tesouro petrolífero da península arábica). Nestas visões fóbicas, a identidade cultural dos povos torna-se uma espécie de chave-mestra que autoriza ou não a articulação de alianças estratégicas. Fatores étnicos afins, similitudes religiosas, semelhanças filosóficas e estilos de vida comuns tornam-se nesta visão de guerra civilizacional fatores tão decisivos nos cálculos estratégicos como recursos naturais e capital.

Nesta concepção na qual a cultura dos povos é um dos fatores centrais do pensamento dos policy-makers, o mundo converte-se num ringue no qual animadores disputam o imaginário popular dos seus e dos que lhes estão próximos, fustigando aqueles que se lhes opõem as crenças e valores. O que está em jogo mais uma vez é o controle simbólico das emoções das massas as imagens construídas do mundo por poderosas estruturas comunicacionais.

É verdade que tal manipulação dos sentimentos e de visões da realidade sempre ocorreram ao longo da história, em especial após a revolução tecnológica que permitiu já nos anos 20 o uso do cinema para os fins da propaganda e persuasão política. Permaneceu verdade na Segunda Guerra Mundial com o rádio e após, ao longo da Guerra Fria, com a televisão. Agora, depois do ataque terrorista à Nova York, tal ação de guerra psicológica assumiu renovado aspecto de gravidade. Domar de alguma forma a cognição humana das populações converte-se em objetivo de primeira grandeza, pois ela serve de ante-sala ao comportamento propriamente dito das pessoas. Preocupa a todos, em especial aos atores posicionados em alerta para esta disputa, no que tais populações crêem e as causas que mobilizam seus espíritos. Em jogo estão questões visíveis como o poder, o domínio e os interesses econômicos. No fundo, permanece a misteriosa dimensão do que as diferentes comunidades consideram sagrado e abominam como profano.

Da mesma forma, tal ansiedade em controlar as crenças e as atitudes expressa a tensão que sociedades multiculturais sentem no seu próprio 
interior. Em Paris, em Londres, em Los Angeles e em Sidney, por exemplo, é visível a dificuldade de interação e integração de grupos que se toleram a distância, fustigados que são pela diferença do outro. Perdidos na multidão, estes grupos vivem nestas aldeias cosmopolitas em guetos por vezes mal disfarçados - à cuidadosa distância de seu semelhante. Nestes ambientes heterogêneos sempre tensos o arcabouço jurídico é armado de tal forma que a discriminação racial e o preconceito são considerados ameaças à própria sobrevivência social e por isso mesmo são pesadamente penalizados. Nas escolas, luta-se pela integração através de uma concepção pedagógica que salienta a diferença como mérito dos grupos. Fala-se à exaustão sobre o direito das minorias.

$\mathrm{O}$ que se quer aqui salientar é que a proximidade física entre estranhos numa comunidade determinada, e a proximidade virtual de comunidades distantes no mundo que interagem através de aparatos tecnológicos e produtos da indústria cultural, revelou esta surpreendente limitação dos humanos: os diferentes convivem com dificuldade. Esta máxima conhecida no âmbito das relações interpessoais (a maioria dos casamentos acaba em divórcio) tornou-se evidente também no âmbito internacional.

Sabe-se disso há tempo, é verdade. No passado recente, por exemplo, os conflitos étnicos tornaram-se tormento cotidiano em países como a antiga Iugoslávia, Albânia e Macedônia. A intolerância entre grupos tem sido repelida com vigor na cultura política mainstream da Europa dos nossos dias exatamente porque o Velho Continente experimentou na Segunda Guerra Mundial a mais dramática experiência de exclusão, segregação e genocídio cultural, racial, religioso e nacional da história, seguida de perto pelos combates tribais da África dos nossos dias.

Em suma, nos espaços multiculturais aprendeu-se a lição: somente uma concepção filosófica que distingue a diferença com o respeito e a proteção da lei autoriza relativa paz social. Ela demanda ainda a promoção do diálogo intercultural em condições de controle e vigilância para que se valorize o esforço que pessoas de boa vontade fazem em promover o enlace dos grupos, apesar de suas histórias díspares e a despeito de suas singularidades. Desde 1848, no nascedouro do nacionalismo moderno, até hoje, num mundo ansioso em não repetir o destino das experiências segregacionistas 
do passado, fala-se com devoção crescente na educação para a paz. No seu âmago está um duplo anseio: primeiro, a promoção da justiça nas próprias comunidades, animando graus superiores de interação intercultural de seus próprios grupos e, segundo, em nível internacional, aumentando a capacidade de tolerância mútua de Nações e Estados, criando, para isso, formas mais competentes de comunicação através das fronteiras.

\section{Áreas de estudo}

É a visibilidade da existência da fronteira política entre estados, e da fronteira cultural entre nações e grupos de uma mesma sociedade, que define, portanto, a existência de duas novas áreas de estudo. A primeira, a da Comunicação Internacional, está interessada no exame dos temas relacionados às trocas simbólicas que ocorrem entre populações de estados distintos. Neste caso, a lista de tópicos que interessaram aos pesquisadores inclui a análise dos fluxos internacionais de notícias e de programas (cinema e TV em especial) assim como na observação dos atores (em especial, a ação internacional das corporações multinacionais e as políticas governamentais de proteção às culturas nacionais e suas medidas de vigilância e controle deste comércio).

Como pano de fundo predominava nos anos 70 a sensação dos países do sul de que se estabelecia no mundo uma nova forma de dominação: o adestramento da mente destas populações que passavam a desejar e imitar um estilo de vida à semelhança dos poderosos. Neste olhar rebelde, de resistência à ação persuasora dos bens simbólicos do norte, entendia-se que bens culturais como os filmes de Hollywood eram uma espécie de arma de guerra. E o resultado buscado e obtido neste tipo de embate era sempre a baixa autoestima do nativo.

Havia nestas queixas um certo clamor de denúncia. Estaria em jogo a identidade dos povos e das culturas locais, regionais e nacionais. $\mathrm{O}$ choque entre a modernidade e a tradição se renovava mais uma vez e o clamor que recusava a inovação e a mudança aliou-se ao espírito anticapitalista popular nos anos 60 e 70 nos países do sul. Ao lado estava também o motivo nacionalista que desejava dar um basta ao predomínio da cultura estrangeira nos seus meios de comunicação e ao predomínio das agências de notícias dos países do norte que dominavam as páginas dos jornais dos países do sul com sua agenda preferencial de tópicos e imagens. 
Decorre deste estado de espírito de modesta rebelião o grito por uma Nova Ordem Internacional da Informação e Comunicação que dominou os debates da Unesco (United Nations Educational, Scientific and Cultural Organization) durante os anos 70. A queixa incluía o desejo por um fluxo mais balanceado de informações capazes de descrever de forma mais equilibrada a realidade dos países do Terceiro Mundo, geralmente apanhados por repórteres da United Press International, Associated Press, Reuters entre outras agências, através de sua faceta mais dolorosa: a discórdia, os desastres, suas revoluções e golpes. No bojo veio o clamor por uma distribuição mais eqüitativa das vagas para o estacionamento de satélites no espaço sideral, por apoio financeiro na construção de redes comunicacionais competentes em seus próprios territórios, e, entre outras medidas, a adoção de políticas de controle dos fluxos dos produtos simbólicos (no Brasil, foram adotadas, à época, políticas de apoio ao cinema nacional e de obrigatoriedade de exibição de filmes brasileiros nos cinemas do país).

Este tom de franca rebeldia, expresso no Brasil também numa polêmica política de proteção à indústria da informática, foi endossado na Unesco por países do Terceiro Mundo e por aliados do bloco soviético dando à celeuma a coloração revolucionária temida por países capitalistas desenvolvidos.

Em outras palavras, os estudos de comunicação internacional se animariam dos choques e entrechoques originários da disputa ideológica da Guerra Fria. No confronto sobre este comércio de bens culturais estavam frente a frente duas visões de mundo: a primeira, a que buscava oferecer proteção ao grupo de nações menos poderoso, apoiando de um lado as políticas que visavam desenvolver a indústria cultural local estimulando, entre outras medidas, o desenvolvimento de recursos humanos e de uma infra-estrutura tecnológica hábil e capaz (redes de telecomunicação e treinamento de jornalistas, por exemplo). A segunda, a que defendia o livre fluxo do comércio, inclusive nesta área específica, agora entendida por todos como igualmente estratégica.

Outra vez, como pano de fundo prevalecia a visão do imperialismo, ou ainda de sua faceta mais radical, a do genocídio cultural (Oliveira, 1991). O pressuposto teórico era de que a comunicação provinda desde um emissor sofisticado posicionado nos países do norte causaria um efeito nos receptores do sul desenvolvendo nestes um desejo de consumo, de ser e sentir incompatíveis com suas tradições. Por isso, deveriam ser repelidos. Via-se na denún- 
cia das referidas corporações internacionais multimídia uma faceta adicional da luta de classes e do conflito internacional entre os poderosos e os fracos. Mobilizados por estas dúvidas e por esta hipótese, a de que a cultura e a informação são igualmente meios poderosos de controle político, estudos variados trataram de revelar a natureza, a dimensão e o volume dos mercados de "enlatados televisivos", de programas jornalísticos, edições de livros, música e moda, da adoção e difusão de inovações, e de estudos de tópicos como o da comunicação para o desenvolvimento e as imagens construídas e destruídas ao longo deste embate pelo imaginário do mundo.

No outro lado, deu-se destaque para as ações de resistência. A cultura popular adquire poder de atração e pesquisadores envolvem-se com seu charme nativista que remetia a uma celebrada essência ameaçada por uma onda modernizante e falsa. No cenário participavam como coadjuvantes a luta pela democratização da América Latina, a rebelião antitecnológica e antimoderna do movimento ambientalista, o fascínio intelectual latinoamericano pela oralidade e a crítica social da indústria cultural, em especial da comunicação de massas. Em apoio, produzia-se a hibridização ideológica do marxismo com o cristianismo. O resultado simbólico deste acasalamento potencializaria, em vários segmentos da opinião pública e em várias regiões do mundo, discursos e ações políticas carregadas de um messianismo soft. A nova utopia místico-religiosa serviria como um rico manancial de esperanças a grupos que provocados por esta interpretação do mundo desenvolveriam programas de leitura crítica da mídia visando ler o não dito, descobrir a fala dos silêncios, a entrelinha, chegando aos bastidores onde, em conluio, estariam os poderosos em articulação maldosa.

A segunda área de estudos, a da Comunicação Intercultural, está interessada em melhorar a capacidade humana de interagir com a diferença. Há que se salientar esta especial peculiaridade: este tipo de ocorrência acontece em qualquer lugar, através das fronteiras políticas e/ou no interior das próprias sociedades, ou seja, entre os integrantes dos grupos portadores dos elementos simbólicos da matriz cultural majoritária e suas minorias e subculturas.

Conceitualmente, há comunicação intercultural sempre que o produtor de uma mensagem for membro de uma cultura e o receptor for participante de outra. De outra forma, a codificação da mensagem pelo emissor posicionado numa certa cultura é feita num ambiente contendo em certo propósito e signifi- 
cado. Tal propósito e significado não são facilmente compreendidos no destino, pelo receptor posicionado no outro extremo, do lado de lá da fronteira, donatário que é de outro repertório de signos e outras experiências históricas. Deriva daí a dificuldade verificada em diversos estudos empíricos sobre a adaptação de diplomatas, estudantes, executivos e outros grupos que são forçados a se adaptar a ambientes estranhos.

Considerando-se a relevância do entendimento do fenômeno cultural para a compreensão da Comunicação Intercultural propriamente dita, saliente-se que não são poucas as definições deste termo. Para os nossos fins cabe assinalar a capacidade que a cultura tem de programar a mente de um indivíduo, predispôla a certo tipo de reação quando estimulada por certa circunstância ou fator ambiental. Na verdade, tais registros contribuem para o estabelecimento de uma relação custo/benefício do processo cognitivo que seja vantajosa, ofertando o máximo de significação com um mínimo de esforço.

Ela ajuda também na relação dos seres com o mundo a partir de certos pressupostos que pouco a pouco são instalados nos seus imaginários através da convivência, educação, rituais, mitos, narrativas, tabus, línguas, celebrações, memória, história e religião, entre outros fatores de aculturação. São estes elementos que estabelecem as identidades humanas - escalas de valores, hábitos, costumes e atitudes distintas - e permitem sua visibilidade no mosaico étnico da humanidade.

É o que explica também o fato de que as percepções são seletivas, pois passam o crivo destes bloqueios sensitivos e cognitivos exigindo esforço para que, no caso da vivência intercultural, seja superada a natural tendência ao etnocentrismo. $\mathrm{Na}$ verdade, a programação da memória tem o benefício de evitar que mais informação tenha que ser processada para que o sistema seja ativado toda vez que for provocado por um elemento inesperado, como ocorre nestes encontros em que as viagens, a diplomacia, os congressos, a imersão, o intercâmbio, e as vizinhanças multiculturais, entre outras experiências, proporcionam. A tendência é ver o novo com os olhos viciados na contemplação do velho, cegos, portanto, ao específico, à natureza própria e íntima da diferença. Para que a imersão afetiva e cognitiva na originalidade alheia ocorra exige-se disposição para o gasto de energia. Este é, como se vê, um exaustivo empreendimento no qual se luta contra a inércia intelectual natural dos seres nos seus contatos com o mundo. Neles predomina, com freqüência, o pensamento o estereótipo e o preconceito. 
Este fato explica o interesse freqüente de especialistas no estudo deste tema das relações interculturais pelo fenômeno da percepção social. $\mathrm{O}$ fato de darmos significados aos objetos com os quais nos defrontamos levando em conta certos padrões de percepção alimentados ao longo de nossa vida pela ambientação cultural circundante constitui-se um condicionante grave que impede e desautoriza com freqüência a emergência do novo frente aos nossos olhos. Da mesma forma, e como assinalado, influencia também gravemente nos nossos julgamentos, pois ora bloqueia, ora autoriza os estímulos que chegam a nossa consciência. De acordo com Hall, quem decide no que prestamos atenção e o que ignoramos é a cultura (Hall, 1986).

Essa função de filtro proporciona uma estrutura ao mundo e protege o sistema nervoso da sobrecarga de informação.

Por isso mesmo, o turismo é uma indústria bem sucedida, pois autoriza um discreto vislumbre do outro em condições de controle sem que se viva e tenha-se a obrigatoriedade de viver o stress da aculturação, da hibridização e da conversão, típicos de outras circunstâncias e experiências, como é o caso da imigração e da colonização, por exemplo. Como síndrome, o choque cultural expressa o elevado grau do stress que emerge no encontro de um observador com outro observado e portador de um grande volume de diferenças, tornando esta empreitada do deciframento um penoso esforço de processamento. O resultado muitas vezes é a pane cognitiva e emocional.

No caso do voyeurismo turístico, o nativo segue as regras do jogo: dispõe sua arranjada singularidade e essência em museus e/ou rotas de desfrute pré-planejados. O viajante, por sua vez, parte a estas jornadas com um olhar bisbilhoteiro, falsamente antropológico. Por isso o turismo funciona: assegura ao viajante o retorno ao ponto de partida, às origens simbólicas que permanecem intactas no aguardo do seu retorno. Há que se dizer por conseqüência, que o turismo é um tipo precário de comunicação intercultural, pois o contato entre estranhos é restrito, passageiro, à distância e sem pretensão. Não é o que ocorre em outras situações de intimidade multicultural forçada onde os pontos de fricção são cotidianos e as tensões por vezes irreconciliáveis.

O estudo destes encontros tem revelado a dimensão psicológica da cultura: serve aos fins de berço emocional, pois assegura aos seres um ninho livre de ambigüidades, aumentando os níveis de previsibilidade e segurança ambiental. As culturas se projetam através de artefatos comunicacionais, objetos 
venerados nas expedições antropológicas, nas quais se busca decifrar os significados mais intensos de distantes e antigas civilizações. Aos membros de uma tribo, tais falas dos seus próprios corpos, de suas vestimentas, de suas tradições e lendas, passam desapercebidas. São naturais e estão incorporadas ao cotidiano. Ao visitante, tudo lhes parece estranho. Aumentar o grau de compreensão mútua entre tais grupos que se olham com espanto é facilitar também, num segundo momento, graus crescentes de tolerância. Este é o problema central que provoca o crescente interesse de autores focados no tema da comunicação intercultural.

Deriva desta peculiaridade o interesse desta área de reflexão e estudo pelo encontro interpessoal de interlocutores posicionados em mundos simbólicos distintos, em especial nos esforços que realizam para superar os obstáculos ao entendimento mútuo. Surge no horizonte o interesse pelos sistemas de crenças, valores e atitudes. No primeiro caso, o das crenças, trata-se de alta probabilidade subjetiva de que algum evento, ou objeto, possua certos tipos de características. No segundo, o dos valores, é a observação que se faz na avaliação que um indivíduo faz da utilidade, benefício, estética, necessidade e prazer dos objetos do mundo e das circunstâncias sociais. Ao definirem o que é certo, ou o que vale a pena, a cultura ajuda as pessoas a fazer escolhas. No terceiro, o das atitudes, observa-se como certa cultura reage de maneira consistente a certo estímulo.

\section{Estudo de caso: terrorismo e o dilema do controle semântico}

Por fim, cabe um breve retorno ao exame dos efeitos e da natureza do ataque de 11 de setembro de 2001 contra as torres gêmeas em Nova York. Há que se assinalar de imediato este aspecto: o terror político tornou-se o tópico preferencial da cobertura noticiosa internacional a partir daquela data, levando o controle semântico desta cobertura a ser um tema controverso. Malabarismos retóricos têm sido tentados, ora para evitar tal classificação do ato, ora para justificá-lo, ora para esvaziá-lo, ora para dotar o terrorismo de aura e glória. $\mathrm{O}$ ataque e seu efeito mortal tornou o terror em (a) dilema central das relações internacionais a partir daquele ano, obrigando alinhamentos e realinhamentos de grupos e nações em torno do tema; (b) acirrou igualmente as tensões interculturais, especialmente os olhares espelhados de ocidentais e muçulmanos, aprofundando por decorrência o desentendimento, a animosi- 
dade e dificultando iniciativas de boa-vontade que nunca cessaram no sentido de evitar uma fratura entre tais grupos que em certos países construíram ambientes multiculturais de grande complexidade, e (c) revelou a potencialidade comunicacional do ato terrorista, convertendo o controle semântico da cobertura jornalística internacional de tais ocorrências em embate no qual envolveram-se governos, grupos de pressão e empresas de comunicação.

Sobre o efeito (a) é possível dizer que vivemos uma nova Era do Terror. Este termo foi utilizado para rotular os anos 70 quando se testemunhou o aumento nos atos terroristas no mundo. Naquela época, aumentou o número de grupos que utilizaram o terrorismo como arma política. Há que se lembrar também que a expansão da televisão nos anos 70 foi fator adicional de estímulo a este tipo de violência, pois a difusão das notícias e de imagens permitia um abalo psicossocial, agora em dimensão planetária.

Outra vez, os ataques realizados a partir de 2001 em lugares distantes como a Tunísia, Marrocos, Bali, Arábia Saudita e no continente africano permitem supor a existência de um plano estratégico arquitetado por grupos islâmicos, geralmente rotulados de fundamentalistas que declararam guerra contra o ocidente e o que ele representa.

$\mathrm{O}$ argumento envolvido é de repulsa política por sua presença militar e cultural no mundo árabe e sua influencia nefasta à identidade islâmica, seus valores e estilo de vida. A tese tem sido repelida pela burocracia oficial de ambos os lados, mas tudo leva a crer que persiste, de fato, no imaginário popular tanto de ocidentais como do resto do mundo, um certo grau de tensão estabelecido entre duas visões de mundo e mentalidades que se chocam na valoração que fazem do papel da mulher na sociedade, na estrutura democrática de sua vida política, no tipo de educação que se dá às crianças, entre outros temas espinhosos que põem de costas não só o mundo muçulmano e o ocidental judaico-cristão como igualmente cria tensões e dificulta o processo de aculturação dos imigrantes muçulmanos e islâmicos que chegam ao ocidente, como é o caso dos argelinos na França e turcos na Alemanha, entre outras localidades. Este é o efeito (b), como assinalado.

Entre as conseqüências geopolíticas mais evidentes deste embate, agora denominado civilizacional, estão o ataque anglo-saxão contra o Iraque, as ameaças americanas aos programas nucleares do Irã (e da Coréia do Norte), as pressões americanas contra a Síria, devido ao apoio que confere aos grupos 
radicais e terroristas do Oriente Médio, o esforço internacional renovado na pacificação do conflito palestino-israelense, o ataque ao Afeganistão e a conseqüente derrota do regime Talibã e, ainda, o envolvimento do Paquistão no esforço ocidental em sua luta contra o terrorismo.

O efeito (c) diz respeito à natureza espetacular do terrorismo e sua natural vocação ao show business. Este fato tem sido assinalado na literatura especializada e tem sido incluído nas mais importantes definições do tema. Conforme Livingstone e Arnold (1986, p. 267), Walter Laqueur chega a afirmar que os meios de comunicação são os melhores amigos dos terroristas e Brian Jenkins formulou sua famosa e repetida máxima: "os terroristas desejam muitas pessoas observando e muitas pessoas ouvindo, mas não muitas pessoas mortas" (apud Livingstone e Arnold, 1986, p. 269).

Para este autor, é a violência que introduz na pauta jornalística a política do terrorista e é ela o instrumento que eles precisam e utilizam para ganhar acesso às redações. Em outras palavras, a barbárie tem alto recall. Conforme Nordstrom e Martin (1992, p. 8) John LeCarré define o terror como ação cênica, teatral ao que Jenkins completa: "terrorismo sem palco não existe." Pierre Bordieu, por isso mesmo, elabora também o conceito de violência simbólica (apud Nordstrom e Martin, 1992, p. 8). Há também a formulação antropológica de que terrorismo é um ritual (Piñuel, 1986, p. 10). Francisco Paulo de Melo Neto (2002) teoriza sobre o marketing do terror. Nesta visão, o terrorista utiliza o crime político como estratégia comunicacional. Desta forma, fornece à mídia os fatos (a mortandade) para a cobertura independente e autônoma dos mass media. $\mathrm{O}$ resultado desta aliança maldita entre o assassinato político e a mídia é o que se vê mundo afora, e ao longo da história: ansiedade generalizada das populações, medo, insegurança e em alguns pontos do globo, pânico. Segundo Melo Neto, criam-se assim catástrofes para ocupar espaços, despertar polêmicas, mistificar o líder terrorista, e criar desacordo entre a imprensa do país alvo e seu governo.

Sendo o terrorismo como é um espetáculo midiático, cabe aos veículos de comunicação de massa contar sua história com palavras, como estória, em capítulos de uma série: com enredo, drama e personagens. São as palavras que explicam ou tentam explicar afinal o assassinato político refletido nas imagens dos telejornais e nas fotos estampadas dos periódicos em todo o mundo. Para não poucos veículos tal narrativa revelou-se, no entanto, um 
imbróglio. Para se safar do mesmo, a BBC inglesa proibiu a seus correspondentes a utilização do termo terrorista. Da mesma forma, o jornal americano Minneapolis Star Tribune modificaria em pelo menos cinco oportunidades despachos do New York Times trocando este vocábulo por 'atacantes' (Independent Media Review and Analysis). A imprensa árabe tem vagado atordoada e ambígua num amplo cardápio de rótulos, entre eles, além de terroristas, também de suicidas e mártires, preferencialmente este. Em Portugal, reclamações fizeram-se ouvir quando o jornal $O$ Público classificou a ETA como organização terrorista.

E George Will, renomado comentarista da rede ABC de TV dos Estados Unidos, não deixaria escapar sem um comentário irônico a decisão da Reuters de cancelar este termo de seu vocabulário. Ele acusaria a agência de notícias inglesa de "corromper a integridade da linguagem" por sua recusa em utilizar o termo maldito. Afinal, diz ele, outros termos também são carregados de conotação pejorativa, como é o caso de violentador, fascista e assassino. Lembra ainda a afirmativa de George Orwell que num ensaio de 1946 afirmou que, "Se o pensamento corrompe a linguagem, a linguagem pode também corromper o pensamento" (Orwell, 1946).

$\mathrm{Na}$ verdade, terrorismo como conceito tomou ares cosmopolitas. Hoje, ele serve a múltiplos fins e causas. Fala-se agora sem cessar também de terrorismo ecológico, de terrorismo econômico, de terrorismo tecnológico, de terrorismo psicológico, entre outros, a ponto de se amenizar semanticamente o terrorismo propriamente dito. Dito de outra forma, serve a tantos propósitos que o único resquício remanescente do conceito original é sua carga emotiva maldita o que explica, por isso mesmo, sua utilização freqüente por atores variados desejosos de usufruir de sua pesada conotação de culpa.

Há que se salientar, por isso, este fato: ao se usar este termo não só se descreve um acontecimento, mas se julga moralmente o evento (Rubenstein, 1987, p. 74-99). No seu bojo há o mal-estar da desaprovação (Simmons, 1991, p. 23-29). E é isso que torna sua utilização tão popular. Compreendese, pois a alternativa de certos setores da imprensa internacional que, como visto, desejam evitar o carimbo semântico que o termo propõe utilizando em seu lugar subterfúgios: torturadores, extremistas, assassinos, seqüestradores, sabotadores, entre outros. Ao sublimarem o termo terrorista e/ou terrorismo por outro cuja carga afetiva é menos explícita tentam evitar a qualquer custo 
o seu envolvimento nos conflitos. Com a salvaguarda de metáforas e equivalente-falsos permanecem de certa forma escondidos e seguros, à espreita, como observadores.

Por decorrência pode-se também compreender o mal e o bem que certas palavras causam, especialmente em momentos de stress nacional nos quais a imprensa vê-se quase abatida no meio do tiroteio de acusações, golpes e contra-golpes. Nestas especiais circunstâncias as palavras pesam muito e a luta por elas e em torno delas é intensa.

Nos casos assinalados percebe-se o mal-estar provocado em amplos setores da opinião pública pela indisposição de editores em assinalar, como terrorista, atos que vitimizam de forma variada civis e inocentes. Por exemplo, o Minnesotans Against Terrorism (MAT), movimento civil de amplo espectro que se formou para protestar contra a política editorial de Star Tribune, mandou publicar no próprio jornal em sua edição de 4 de janeiro de 2002, anúncio de página inteira na qual afirmavam que "terroristas são terroristas." O diário saudita baseado em Londres Al-Sharq Al-Awsat preferiu nominar de "atacantes suicidas" os terroristas, prática que lhe rendeu amplas críticas no mundo árabe. Os periódicos americano e saudita teriam que esboçar na defesa de suas posições ampla argumentação teórica e filosófica sobre suas políticas editoriais. O editor assistente do Star, Roger Buoen, explicaria:

Nossa prática é ficar longe da caracterização de sujeitos de nossas matérias preferindo descrever suas ações, informação de contexto e identidade de uma forma tão completa quanto possível, permitindo que nossos leitores façam seus julgamentos sobre indivíduos e organizações. [...] No caso do termo terrorista, outros termos - 'atirador', 'separatista' e 'rebelde' - podem ser mais precisos e menos provavelmente vistos como juízos de valor. Por causa disso preferimos palavras mais específicas (Fairness \& Accuracy in Reporting, 8 abr. 2002).

Abd Al-Rahman Al-Rashed, editor do Al-Sharq, forçado pelo mesmo debate mas noutra conjuntura, a das pressões para nominar terroristas de mártires, afirmou: "em nosso jornal, nos esforçamos para realizar um trabalho de reportagem contido. Esta é uma imposição ditada a nós pela profissão, não pelos leitores" (Al-Sharq, 10 maio 2002 e 20 abr. 2002).

Seu argumento era favorável à neutralidade na descrição dos fatos numa versão similar à aplicada na Reuters, como referido, que em memorando interno comentou: 
Sabemos todos que o terrorista de um é o libertador de outro e a Reuters sustenta o ponto de vista de não se usar o vocábulo terrorista. [...] Sendo franco, acrescenta pouco chamar o ataque ao World Trade Center de ataque terrorista (Independent media review and analysis).

$\mathrm{Na}$ verdade, há enorme ambigüidade e confusão em torno desta decifração. O Oxford English Dictionary utilizou o termo pela primeira vez em 1795 ao se referir aos acontecimentos do terror pós-revolucionário da França. A história do termo inclui também sua utilização na descrição dos conflitos agrários da Irlanda no século XIX, na onda de crimes políticos realizados pelo Narodnaya Volya (A Vontade Popular) em especial contra o regime Tzarista de Alexander II, nas ações do movimento anarquista também no século XIX e noutras ocorrências, a partir dos anos 40 do século XX, cujas motivações tinham ora fundamento nacionalista, ora religioso, étnico, ideológico, racial, político e social entre outros.

Nesta Babel lingüística e conceitual o terrorismo mesmo acaba no melhor dos casos sendo inocentado, e no pior o peso da condenação moral aliviada. A conceituada obra de referência de Alex Schmid tentaria superar esta embaraçosa situação ao examinar 109 definições de terrorismo identificando 22 elementos presentes em todas elas. São eles: (1) as presenças da violência, (2) de um fator político mobilizador, (3) do medo, (4) e da ameaça. (5) O ato visa obter efeitos psicológicos. (6) O alvo é selecionado. (7) Trata-se de ação organizada, planejada, intencional e sistemática, (8) sendo por isso método de combate estratégico e tático, (9) que não leva em conta qualquer constrangimento humanitário e que (10) busca através da coerção certo resultado. (11) Possui uma dimensão publicitária (12), pois tem um aspecto simbólico que deseja demonstrar algo para outras pessoas muito embora seja (18) impessoal. (19) Tal ação visa atingir civis não combatentes, tendo como meta final à intimidação. (20) Há uma ênfase na inocência da vítima e o responsável é (21) um grupo, movimento ou organização. (22) Sua ação é imprevisível, clandestina, repetitiva, criminosa, visando fazer exigências.

Deriva desta constatação a definição deste autor ao fenômeno: terrorismo é um método de produção de ansiedade graças à ação violenta repetida, empregada por indivíduo (semi) clandestino, grupo, ou atores estatais por razões idiossincráticas, criminais ou políticas, e na qual as vítimas diretas da violência não são alvos principais. Estas vítimas humanas imediatas são escolhidas 
ao acaso (alvos de oportunidade) ou seletivamente (representantes por alvos simbólicos) de uma população alvo, e servindo como geradores de mensagens. Processos de comunicação baseados na ameaça e violência entre a (organização) terrorista, a vítima (em perigo) e os principais alvos são utilizados para manipular o principal alvo (audiência), tornando-a alvo do terror, alvo de demandas, alvo de atenção, dependente do fato se a intimidação, a coerção, ou a propaganda são buscadas.

A Organização das Nações Unidas interviria igualmente neste embate lingüístico. Baseando-se na conceituação de Schmid aprovaria sua própria definição em termos muito similares aos daquele autor. Nos Estados Unidos, distintos órgãos públicos utilizam-se de diferentes elaborações. O rótulo e seu significado constituem-se, portanto, em motivo grave de disputa. Em jogo está a legitimidade do ato. Para Simmons, a crença que persiste é o poder que a palavra de fato possui no enquadramento do pensamento (Simmons, 1991, p. 24). Este fato explica, em decorrência, a tradição de pesquisa sobre diferenciação semântica que scholars de comunicação tem realizado sobre o viés do discurso jornalístico do fenômeno do terrorismo. O que motiva este tipo de olhar microscópico dos rótulos é perceber os valores implícitos de julgamento e seu provável efeito nos receptores. Nesta visão, sinônimos não são equivalentes e remetem a significados distintos graças a decisivas sutilezas semânticas. Em disputa, está o grau de conotação emotiva. Conforme Simmons, o troféu em disputa é a vitória psicológica, como afirmam Schmid e de Graff (Simmons, 1991, p. 24).

Simmons refere-se a Weimann (Simmons, 1991, p. 27) que levantou a hipótese de uma correlação inversa entre a distância geográfica, a distância política e a taxa de violência de um evento político e a avaliação positiva de um rótulo para descrever os terroristas. Entre as hipóteses exploradas estão as de que, por exemplo, revistas americanas rotulam eventos como terroristas mais freqüentemente quando as vítimas são americanas, ou, ainda, quando se opõem à política americana, havendo também uma correlação positiva entre o grau de carnificina resultante de um ato terrorista e o uso negativo do rótulo.

Picard e Adams (1991, p. 12-21) concluíram que jornalistas e fontes testemunhais de atos violentos utilizavam em suas descrições caracterizações nominais (substantivos, gerúndios e/ou outras palavras que descrevem o evento), sem traço sensacionalista. Já autoridades governamentais faziam 
referências descritivas, com intensa formulação adjetivada e com juízos de valor implicados (assassinos, criminosos e covardes). Revoltados, inflamavam ainda mais o ambiente.

\section{Conclusão}

O estudo de caso realizado teve o objetivo de ilustrar com um exemplo concreto da atualidade a dificuldade existente nas relações internacionais da percepção social de grupos e nações sobre temas controversos e dilemas existenciais graves. Da mesma forma, ilustra o papel que a comunicação exerce no trato semântico deste fenômeno específico de violência e homicídio político contra civis. Esta é, no entanto, somente uma das várias preocupações da Comunicação Internacional. Inúmeras outras, como assinalado, existem. Entre elas estão o estudo comparado das estruturas tecnológicas que autorizam ou não a produção e disseminação de bens simbólicos entre estados e grupos sociais dentro de uma sociedade multicultural; o conteúdo das mensagens noticiosas e seus atores; a regulamentação oficial desta atividade jornalística; os fenômenos do turismo e das corporações multinacionais no âmbito da cultura.

Subjacentes estão as preocupações sobre os eventuais efeitos que os filmes, a música, a moda, o noticiário e os livros causam no modo de vida, nos valores e nas imagens de certo público alvo de uma nação e sociedade. Segundo esta visão, o emissor deseja de alguma forma exercer alguma influência sobre a percepção de seus colonizados, e/ou dos povos em sua esfera de influência política, assim como de grupos nacionais que exercitam um estilo de vida que lhes parece ameaçador e por isso necessita ser detido ou contido.

Foi a vocação colonial, por exemplo, que orientou a origem da BBC londrina antes ainda da II Guerra Mundial, quando exerceria papel histórico na luta psicológica contra o III Reich. Serviria de exemplo ao aparecimento posterior do fenômeno da radiodifusão internacional com a emergência de várias emissoras similares, entre elas a Voz da América. Hoje tal papel é levado a cabo igualmente por emissoras particulares que cobrem os eventos do mundo desde a perspectiva de suas próprias culturas e interesses geopolíticos nacionais, tornando-se, por isso, foco de interesse de scholars dedicados ao estudo deste tópico. 
A comunicação internacional como área de estudo preocupa-se ainda com eventuais desequilíbrios nestes fluxos entre nações e grupos de bens simbólicos no que se refere à sua direção, quantidade e qualidade dos conteúdos de tal produção. Interpretações sobre o significado de tais trocas por vezes autorizam diagnósticos que apontam ora para uma forma de imperialismo, ora para dependência, ora ainda para o genocídio cultural. Em outras falas, o encontro intercultural parece ser uma guerra civilizacional. Em tais debates emergem temas como as ocorrências da propaganda política, da persuasão em tempo de paz e de guerra e da manipulação cultural.

A Comunicação Intercultural registrou há muito a dificuldade que os seres humanos possuem em conviver com a diferença, em especial nos ambientes marcadamente multiculturais. Deriva daí a preocupação essencial desta área de estudo em melhorar esta capacidade de interação avaliando, com isso, o papel que o registro cultural tem na facilitação e problematização de tal convivência. Deseja e ambiciona ser um instrumento que atua a favor da paz.

Tanto a Comunicação Internacional, como a Intercultural acumularam saberes úteis e necessários num mundo que se torna, como dito, crescentemente enredado e onde as trocas são mais velozes, as fronteiras são menos rígidas e a convivência social e internacional, por isso mesmo, mais tensas.

O terror é um, e somente um, exemplo de road block entre os vários existentes no alcance deste objetivo. Mas é um exemplo dramático por sua atualidade política, por sua dimensão publicitária e comunicacional e por expressar ambos os impasses: o de um controverso conceito de guerra cultural entre atores dispostos em berços simbólicos distantes; e de comunicação internacional, quando se observa o uso e mal uso das palavras na sua descrição e análise.

\section{Referências}

ALALAI, Odasuo; EKE, Kenonye Kelvin (orgs.). Media coverage of terrorism: methods of diffusion. London: Sage, 1991.

GUELKE, Adrian. The age of terrorism and the international political system. London/New York: I.B. Tauris, 1995.

HALL, Edward. A dimensão oculta. Lisboa: Antropos, 1986. 
HUNTINGTON, Samuel P. O choque das civilizações e a recomposição da ordem mundial. Rio de Janeiro: Objetiva, 1997.

JOHNSON, Larry. The future of terrorism. American Behavioral Scientist, v. 44, n. 6, p. 894-913, fev. 2001.

LIVINGSTONE, Neil. C. The war against terrorism. Lexington: Lexington, 1982.

- ; TERREL, Arnold. Contra-ataque para vencer a guerra contra o terrorismo. Rio de Janeiro: Nórdica, 1986.

MELO NETO, Francisco Paulo de. Marketing do terror. São Paulo: Contexto, 2002.

NORDSTROM, Carolyn; MARTIN, Joann. The paths to domination, resistance, and terror. University of California Press, 1992.

OLIVEIRA, Ômar Souki. Genocídio cultural. São Paulo: Paulinas, 1991.

ORWELL, George. Politics and the english language. 1946. Disponível em: http://www.resort.com/ prime8/Orwell/patee.html. Último acesso: 22 set. 2005.

PICARD, Robert; ADAMS, D. Characterizations of facts and perpetrators of political violence in three elite US daily newspapers. In: ALALAI, O. A.; EKE, Kenonye Kelvin (orgs.). Media coverage of terrorism: methods of diffusion. London: Sage, 1991, p. 12-21.

PIÑUEL, Jose Luis. El terrorismo en la transición española. Madrid: Fundamentos, 1986.

RUBENSTEIN, R. Terrorism, the media, and the liberal-democratic state: a critique of orthodoxy. Social Research, n. 42, p. 74-99, 1987.

SCHMID, Alex. Political terrorism: a new guide to actors, authors, concepts, data base, theories and literature. New York: North-Holland Publishing Co., 1988.

SIMMONS, Brian. K. US newsmagazines labeling of terrorists. In: ALALAI, O. A.; EKE, Kenonye Kelvin (orgs.). Media coverage of terrorism. Methods of diffusion. London: Sage, 1991, p. 24.

Recebido em 15 de janeiro de 2005 e aprovado em 20 de julho de 2005 